\title{
An Empirical Investigation of the Impact of Intrinsic Rewards on Employees Loyalty
}

\author{
HAZRAT BILAL \\ (Corresponding Author) \\ Assistant Professor, Centre for Management and Commerce, University of Swat. \\ Email: hbilal@uswat.edu.pk \\ Tel: 03339888140
}

ASHFAQ AHMAD

Assistant Professor, Centre for Management and Commerce, University of Swat Email: Ashfaqahmad79@outlook.com

\section{PALWASHA BIBI}

Assistant Professor, Centre for Management and Commerce, University of Swat. Email: Dr.palwashabibi@gmail.com

\begin{abstract}
The aim of this paper was to study the impact of intrinsic rewards on loyalty of employees working in restaurants situated in district Swat. This cross-sectional study was quantitative in nature and used nonprobability sampling of 202 employees from restaurants. The self-administered questionnaire included demographic section, the intrinsic rewards and Swat Loyalty Scale (SLS). The data was analysed by applying Pearson Correlation and Regression. The results of the study confirmed a positive and significant relationship between intrinsic rewards and employee loyalty of employees working in restaurants. This study contributes to the employee loyalty Literature and, more specifically, to the relationship between intrinsic rewards and loyalty in the restaurants sector of district Swat. The outcome of the study draws the attention of decision makers to the importance of intrinsic rewards and its impact on the employee loyalty.
\end{abstract}

Keywords: Intrinsic Rewards, Employee Loyalty, Swat Loyalty Scale, Restaurants.

\section{Introduction}

Intrinsic rewards have direct impact on employee attitude (Ajmal, Bashir, Abrar, Khan, \& Saqib, 2015). According to Thomas (2009), intrinsic rewards are intangible and inherit in a job. Organizations whose employees believe they are rewarded fairly will see their employees put in their best effort in their work. Organizations plan and execute rewards programmes to recruit and retain workers. These rewards of employees do not just emphasize on financial compensation but these also include recognition from superiors, praise, opportunity to initiate different tasks and autonomy and receiving leadership attention (Riasat, Aslam, \& Nisar, 2016; Shujaat \& Alam, 2013). Such rewards are called intrinsic rewards (K. Thomas, 2009).

Employee loyalty benefits the organization in the form of generating high profit and increase efficiency and reducing employee turnover cost (Ganesh, Arnold, \& Reynolds, 2000). Loyalty is the willingness of an employee to remain with the organization (Solomon, 1992) and is a type of organizational citizenship behaviour that expresses a dedication to the organization's goals and the promotion of its image to outsiders 
(Bettencourt, Gwinner, \& Meuter, 2001). Any organization that wants to be effective and to retain its employees must ensure the employees loyalty. An organization with a higher number of loyal employees tends to be more competitive and loyal employees are found to be more efficient than those who are not loyal (Bilal, Waseem, \& Ali, 2020).

Intrinsic rewards positively affect the employee attitudes such as job satisfaction (Mottaz, 1985; Tausif, 2012), motivation (Csikszentmihalyi, 1978; Tippet \& Kluvers, 2009), employee performance (Danish, Khalid Khan, Shahid, Raza, \& Humayon, 2015; Khan, Shahid, Nawab, \& Wali, 2013) and work engagement (Hua, Cheng, Hou, \& Luo, 2020; Victor \& Hoole, 2017) but no study to date is conducted on the relationship between intrinsic rewards and loyalty. The intrinsic rewards includes behavioural elements with focus on mutual benefits as outlined in the Social Exchange Theory of Blau (1964). According to this theory, if an employee is rewarded properly, will exhibit a positive behaviour called loyalty. Therefore, objective of this research is to empirically examine the impact of intrinsic rewards on employee loyalty.

\section{Literature Review}

\section{Intrinsic Rewards}

Intrinsic rewards are the performing of a job for its inherent satisfaction rather that for a tangible benefit. Such rewards are psychological or emotional rewards derived from employee experiences gained from doing their meaningful work and working environment (K. Thomas, 2009). The Intrinsic rewards are nonphysical. They can't be seen or touched, but they have a deep emotional connection with the job. To put it another way, intrinsic rewards are the feelings of satisfaction that come from fulfilling a job (Khern-amnuai, Kannan, \& Ghasemkhani, 2018). Employee motivation requires intrinsic rewards such as satisfaction at fulfilling a job requirements and feelings of accomplishments (Frey \& Oberholzer-Gee, 1997).

Intrinsic rewards are non-physical, intangible, and emotionally driven from work well done (Michael, 2019). Even if they can't be seen or touched, they still have emotional and motivational power. They are generally associated with feelings of pride, happiness, or appreciation of a job well done. The intrinsic reward comes from the inside of an individual who performs a task or shows the required behaviour (Michael, 2019). Work that offers an exciting, stimulating, meaningful, pleasant, satisfying experience with variety and advancement opportunities, as well as an atmosphere that provides positive feedback, is intrinsically rewarding (Jacobs, Renard, \& Snelgar, 2014).

According to K. Thomas (2009), intrinsic rewards including a sense of meaningfulness, choice, competence and progress. Sense of meaningfulness is the purpose an individual willing to fulfil. Meaningfulness refers to the belief that one's work is worthwhile and serves a greater function. Such beliefs of employee sustain motivation over the long run (Thomas, 2009). Employees are empowered to be selfdirected, autonomous, and accountable for their job results when they have the choice to determine their own activities and methods of carrying out these activities. Sense of competence is an employee continuously learning and efforts, which means that employees feel able to handle their work activities and perform themselves in ways that meet or surpass their individual performance standards. Sense of progress is an individual feeling that work is on right direction and accomplishing the desired outcomes (Thomas, 2009).

\section{Employee Loyalty}

Employee loyalty is the trust, identification, commitment, participation and attachment of an employee towards organization in order to improve its performance (Guillon \& Cezanne, 2014). It is wholehearted devotion to an organization and a positive presentation of the organization to the community in general (Ladd, 1987). Employees are regarded as the core of the organization and their performance determine 
whether the organisation succeeds or fails. It is of paramount importance that employees are loyal to the organisation and do not actively seek alternative opportunities (Murali, Poddar, \& Seema, 2017).

A loyal employee is more likely to function efficiently toward organisational objectives and to demonstrate productivity and customer orientation (Wan, 2012). Therefore, organizations preliminary focus on the development and enhancement of employee loyalty (Wan, 2012). Highly loyalty of employee leads an organization to increase levels of customer loyalty, high efficiency, lower recruiting cost and innovation (Ganesh et al., 2000; Moorman \& Blakely, 1995).

Employee loyalty is a critical factor for organizations, especially in the service industry (Antonova, 2016). It can improve an organization's success in a variety of ways, including lowering employee turnover, increasing profits, credibility, and enhancing overall efficiency (Guillon \& Cezanne, 2014; Heskett, Jones, Loveman, Sasser, \& Schlesinger, 1994). This may also be due to the fact that workers who have a strong sense of loyalty to their employer are more likely to be concerned for their employer's well-being. Employees can also put their own interests on hold in order to prioritise the interests of their employer, which may show itself as the employee staying longer or working harder than anticipated (Pandey \& Khare, 2012; Wiklund \& Jansson, 2019). According to Bilal et al. (2020), employee loyalty refers to a person's cognitive, physical, and emotional contribution to an organization. The cognitive component of loyalty is the willingness to always learn, advance, and take pride in one's work. These individuals are committed, positive, and adhere to the organization's policies. Physical measurements indicate a person's readiness, willingness, and ability to perform organisational tasks. Positive thoughts, gestures, and memories of someone who is qualified to do a particular job within an organisation are referred to as emotional dimensions.

\section{Relationship between Intrinsic Rewards and Employee Loyalty}

According to an earlier study conducted by K. Thomas (2009), the results indicated a positive and significant relationship between intrinsic rewards and employee attitude. In similar study conducted by Jacobs et al. (2014), the results also revealed that intrinsic rewards significantly and positively influence employee attitude like work engagement of employees working in South African retail organizations. Intrinsic rewards are non-cash rewards or rewards that do not have a tangible nature. Employee recognition, acknowledgement, professional development, immediate task authority, gratitude, and appreciation, for example, are intrinsic rewards (Ajmal et al., 2015). Based on the social exchange theory of Blau (1964) and reciprocity theory of Cropanzano and Mitchell (2005), the intrinsic rewards leads to more loyalty of employees. Therefore, on the basis of this theory and literature, we hypothesize that:

H1: Intrinsic rewards have significant and positive impact on employee loyalty working in restaurants.

\section{Objectives of the Study}

The objective of this research is to explore the relationship between intrinsic rewards and loyalty of employees working in the resturants situated in district Swat.

\section{Methodology}

\section{Sample and Collection of Data}

The population for this study was the total number of employees working in resturants situated in district Swat. A non-probablity convinient sample of 235 employees was selected. All 235 self administered questionnaires were sent to the managers and stewards working in these resturants and 202 usable questionnaire were returned, which represnented a response rate of $86 \%$. 


\section{Measurements}

The intrinsic rewards was measured with a scale of 7 items used by Allen Richard and Kilmann Ralph (2001). Whereas the loyalty was assessed by 19 items Swat Loyalty Scale (SLS) of Bilal et al. (2020). Question No:12 of SLS was considered as a reverse coded question as "I don't avoid the misuse of my organization's resources" for the propose of correct scoring and so that the respondense could response with care and avoid biasness. Both the scales were measured through a 5-five likert scale starting from strongly disagree to strongly agree. All the respondents were male and no female respondent was found. This lack of female respondents may be due to the male dominent society and culture of the local area.

\section{Results}

\section{Respondents Demographics}

The demographic analysis of 202 respondents on the basis of gender, age, education and experience is revealed below in Table 1 .

Table 1: Demographic Analysis

\begin{tabular}{|c|c|c|c|c|c|}
\hline \multicolumn{2}{|c|}{$\mathrm{co}$} & Frequency & Percent & $\begin{array}{c}\text { Valid } \\
\text { Percent }\end{array}$ & $\begin{array}{c}\text { Cumulative } \\
\text { Percent }\end{array}$ \\
\hline Gender & Male & 202 & 100 & 100 & 100 \\
\hline \multirow[t]{4}{*}{ Marital Status } & Married & 93 & 46.0 & 46.3 & 46.3 \\
\hline & Unmarried & 108 & 53.5 & 53.7 & 99.5 \\
\hline & Missing & 1 & 0.5 & 100 & 100 \\
\hline & 20 or Below & 22 & 10.9 & 10.9 & 10.9 \\
\hline \multirow[t]{4}{*}{ Age } & 21 to 30 & 133 & 65.8 & 65.8 & 76.7 \\
\hline & 31 to 40 & 29 & 14.4 & 14.4 & 91.1 \\
\hline & 40 to 50 & 18 & 8.9 & 8.9 & 100.0 \\
\hline & 10 Years Schooling & 35 & 17.3 & 17.3 & 17.3 \\
\hline \multirow[t]{6}{*}{ Education } & 12 Years Schooling & 70 & 34.7 & 34.7 & 52.0 \\
\hline & 14 Years Schooling & 85 & 42.1 & 42.1 & 94.1 \\
\hline & 16 Years Schooling & 12 & 5.9 & 5.9 & 100.0 \\
\hline & Less than 1 year & 30 & 14.9 & 14.9 & 14.9 \\
\hline & 1 to 5 years & 63 & 31.2 & 31.2 & 46.0 \\
\hline & 6 to 10 years & 30 & 14.9 & 14.9 & 60.9 \\
\hline \multirow[t]{3}{*}{ Experience } & 11 to 15 years & 54 & 26.7 & 26.7 & 87.6 \\
\hline & 16 and above years & 25 & 12.4 & 12.4 & 100.0 \\
\hline & Total & 202 & 100.0 & 100.0 & \\
\hline
\end{tabular}

\section{Reliability Analysis}

The Cronbach's Alpha value of reliability analysis for intrinsic rewards was calculted 0.755 and 0.835 shown in Table 2 below. Both th values are above the thresshold value of 0.70, which allow us for further statistical analysis (Nunnally, 1978).

Table 2: Reliablity Analysis

\begin{tabular}{|lcc|}
\hline & Cronbach's Alpha & No of Items \\
\hline Intrinsic Rewards & 0.755 & 7 \\
Swat Scale of Loyalty & 0.835 & 19 \\
\hline
\end{tabular}




\section{Correlational Analysis}

Table 3 depicts mean, standard deviation and correlation between dependent and independent variables. The mean value of intrinsic rewards is 3.075 , which explains that most of the respondent's opinion recorded was agrees and neutral about the intrinsic rewards, with a standard deviation value of 0.668 . The mean value employee loyalty is 3.078 , which also explains that most of the respondent's options were agree and neutral about the employee loyalty, whereas the standard deviation is 0.433 , which shows the deviation of results from the target. Further, the results of the Pearson correlation shown in Table 3, produces a significant correlation $(\mathrm{r}=0.553, \mathrm{p}<.001, \mathrm{~N}=202)$.

Table 3: Mean, Standard Deviation and Correlation

\begin{tabular}{|lcccccc|}
\hline & Mean & $\begin{array}{c}\text { Std. } \\
\text { Deviation }\end{array}$ & $\begin{array}{c}\text { Intrinsic } \\
\text { Rewards }\end{array}$ & $\begin{array}{c}\text { Employee } \\
\text { Loyalty }\end{array}$ & $\begin{array}{c}\text { Sig (2- } \\
\text { tailed) }\end{array}$ & $\mathbf{N}$ \\
\hline Intrinsic Rewards & 3.075 & .668 & 1 & 0.553 & 0.000 & 202 \\
Employee Loyalty & 3.078 & .433 & 0.553 & 1 & 0.000 & 202 \\
\hline
\end{tabular}

\section{Regression Analysis}

The model summary and overall fit statistics results are shown in Table 4 . The value of adjust $R^{2}=0.302$ with the $\mathrm{R}^{2}=0.306$, that means that the linear regression explains $30.6 \%$ of the variance in the data. The Durbin-Watson $\mathrm{d}=1.791$, is below 2.5 and hence it assures that there is no first order linear autocorrelation in the data.

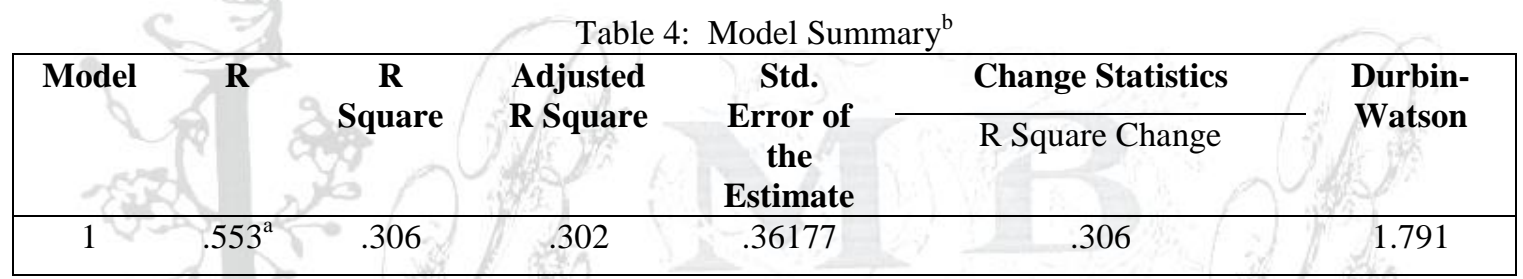

a. Predictors: (Constant), Intrinsic Rewards

b. Dependent Variable: Employee Loyalty

Table 5 portrays the F-test, with $\mathrm{F}=88.033$ and 201 degrees of freedom, shows a highly significant results, thus prove that there is a significant relationship between the two varaiables.

\begin{tabular}{|clccccc|}
\hline \multicolumn{7}{c|}{${\text { Table 5: } \text { ANOVA }^{\mathrm{a}}}$} \\
\end{tabular}

a. Dependent Variable: EL

b. Predictors: (Constant), ER

Table 6 shows the regression coefficients and the intercept in the model. The results of linear regression analysis estimated the linear function as $\mathrm{y}=1.978+0.358$, with a $\beta=0.358, \mathrm{t}=9.383$ and $\mathrm{p}<0.001$. Furthermore, the multicollinearity was diagnosed in the data through Tolerance and Variance Inflation Factor (VIF). The values of both Tolerance and VIF are equal to one, and hence determine no multicollinearity in the model. 
Table 6: Coefficients ${ }^{\mathrm{a}}$

\begin{tabular}{|c|c|c|c|c|c|c|c|}
\hline \multirow[t]{2}{*}{ Model } & \multicolumn{2}{|c|}{$\begin{array}{c}\text { Unstandardized } \\
\text { Coefficients } \\
\end{array}$} & \multirow{2}{*}{$\begin{array}{c}\begin{array}{c}\text { Standardized } \\
\text { Coefficients }\end{array} \\
\text { Beta }\end{array}$} & \multirow[t]{2}{*}{$\mathbf{t}$} & \multirow[t]{2}{*}{ Sig. } & \multicolumn{2}{|c|}{$\begin{array}{c}\text { Collinearity } \\
\text { Statistics } \\
\end{array}$} \\
\hline & $\mathrm{B}$ & $\begin{array}{l}\text { Std. } \\
\text { Error }\end{array}$ & & & & Tolerance & VIF \\
\hline $\begin{array}{ll}1 & \text { (Constant) } \\
\text { ER }\end{array}$ & $\begin{array}{l}1.978 \\
.358\end{array}$ & $\begin{array}{l}.120 \\
.038\end{array}$ & .553 & $\begin{array}{c}16.467 \\
9.383\end{array}$ & $\begin{array}{l}.000 \\
.000\end{array}$ & 1.00 & 1.00 \\
\hline
\end{tabular}

a. Dependent Variable: EL

The homoscedasticity and normality of residuals was also checked by normal distribution and by PP Plot of $z^{*}$ pred and $z^{*}$ presid. The results shown in figure 1 and 2 depicts that in our linear regression analysis there is no tendency in the error terms and hence found no outliers.

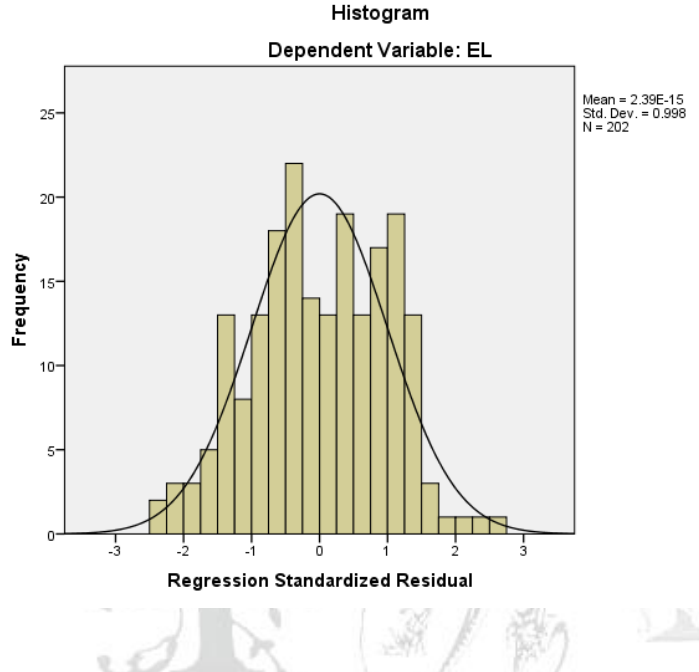

Figure 1: Normal Distribution

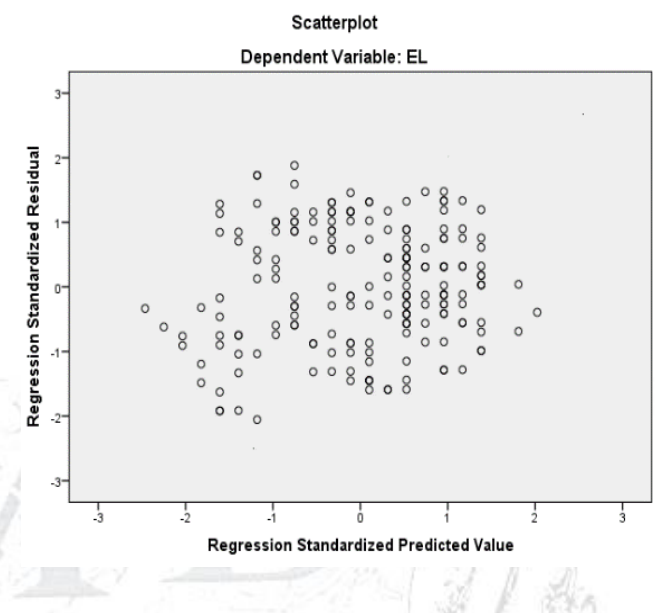

Figure 2: Regression standardized residual of intrinsic rewards and employee loyalty

\section{Discussion and Conclusion}

The prime objective of the current research was to analyse the relationship between intrinsic rewards and employee loyalty. There are few evidences available in literature, which clearly shows the relationship between intrinsic rewards and employee attitudes (Ajmal et al., 2015; Tausif, 2012), but no evidence is found about direct relationship between intrinsic rewards and employee loyalty. Ajmal et al. (2015) discovered that intrinsic reward plays a significant role in employee engagement and employee satisfaction, which leads employees toward high level of loyalty and organizational commitment. Employee attitudes vary depending on how they perceive the organization's support, and how they perceive various types of motivational techniques such as intrinsic rewards (Ajmal et al., 2015). Therefore, on the basis of literature and our research analysis we concluded that intrinsic rewards have significant and positive impact on loyalty of employees working in restaurants situated in district Swat

\section{Limitations and Future Research Recommendations}

This study has few limitations. Firstly, this study was conducted in an area where none of the female were found working in restaurant sector, thus entails cultural and socio-economic factors that may limit the potential level of generalization of the current study. Therefore, a similar study may be replicated in future in other parts of the country considering both male and female respondents in order to generalized this 
study results. Secondly, the data was collected only from restaurants situated in district swat, therefore, a similar study may also be conducted in Hotels and other service sectors to better understand the impact of intrinsic rewards on employee loyalty.

\section{References}

Ajmal, A., Bashir, M., Abrar, M., Khan, M. M., \& Saqib, S. (2015). The effects of intrinsic and extrinsic rewards on employee attitudes; mediating role of perceived organizational support. Journal of Service Science and Management, 8(04), 461.

Allen Richard, S., \& Kilmann Ralph, H. (2001). The role of the reward system for a total quality management based strategy. Journal of Organizational Change Management, 14(2), 110-131. doi: $10.1108 / 09534810110388036$

Antonova, E. (2016). Occupational Stress, Job Satisfaction, and Employee Loyalty in Hospitality Industry: A Comparative Case Study of Two Hotels in Russia: Master Thesis: Modul University.

Bettencourt, L. A., Gwinner, K. P., \& Meuter, M. L. (2001). A comparison of attitude, personality, and knowledge predictors of service-oriented organizational citizenship behaviors. Journal of applied psychology, 86(1), 29.

Bilal, H., Waseem, M., \& Ali, S. (2020). Pragmatic Impact of Loyalty on Deviant Workplace Behavior among Banking Sector Employees. Journal of Accounting and Finance in Emerging Economies, 6(2), 407-414.

Blau, P. M. (1964). Justice in social exchange. Sociological Inquiry, 34(2), 193-206.

Cropanzano, R., \& Mitchell, M. S. (2005). Social exchange theory: An interdisciplinary review. Journal of management, 31(6), 874-900.

Csikszentmihalyi, M. (1978). Intrinsic rewards and emergent motivation. The hidden costs of reward: New perspectives on the psychology of human motivation, 24(3), 205-216.

Danish, R. Q., Khalid Khan, M., Shahid, A. U., Raza, I., \& Humayon, A. A. (2015). Effect of intrinsic rewards on task performance of employees: Mediating role of motivation. International Journal of Organizational Leadership, 4, 33-46.

Frey, B. S., \& Oberholzer-Gee, F. (1997). The cost of price incentives: An empirical analysis of motivation crowding-out. The American economic review, 87(4), 746-755.

Ganesh, J., Arnold, M. J., \& Reynolds, K. E. (2000). Understanding the customer base of service providers: an examination of the differences between switchers and stayers. Journal of marketing, 64(3), 65-87.

Guillon, O., \& Cezanne, C. (2014). Employee loyalty and organizational performance: a critical survey. Journal of Organizational Change Management.

Heskett, J. L., Jones, T. O., Loveman, G. W., Sasser, W. E., \& Schlesinger, L. A. (1994). Putting the service-profit chain to work. Harvard business review, 72(2), 164-174.

Hua, Y., Cheng, X., Hou, T., \& Luo, R. (2020). Monetary rewards, intrinsic motivators, and work engagement in the IT-enabled sharing economy: A mixed-methods investigation of Internet taxi drivers. Decision Sciences, 51(3), 755-785.

Jacobs, S., Renard, M., \& Snelgar, R. J. (2014). Intrinsic rewards and work engagement in the South African retail industry. SA Journal of Industrial Psychology, 40(2), 1-13.

Khan, I., Shahid, M., Nawab, S., \& Wali, S. S. (2013). Influence of intrinsic and extrinsic rewards on employee performance: The banking sector of Pakistan. Academic Research International, 4(1), 282.

Khern-am-nuai, W., Kannan, K., \& Ghasemkhani, H. (2018). Extrinsic versus intrinsic rewards for contributing reviews in an online platform. Information Systems Research, 29(4), 871-892.

Ladd, J. (1987). London: Macmillan Publishing Co. The Free Press.”: Loyalty.

Michael, A. (2019). A handbook of human resource management practice: bookboon. com.

Moorman, R. H., \& Blakely, G. L. (1995). Individualism-collectivism as an individual difference predictor of organizational citizenship behavior. Journal of Organizational Behavior, 16(2), 127-142.

Mottaz, C. J. (1985). The relative importance of intrinsic and extrinsic rewards as determinants of work satisfaction. The sociological quarterly, 26(3), 365-385. 
Murali, S., Poddar, A., \& Seema, A. (2017). Employee loyalty, organizational performance \& performance evaluation-a critical survey. IOSR Journal of Business and Management, 19(8), 62-74.

Nunnally, J. C. (1978). An overview of psychological measurement Clinical diagnosis of mental disorders (pp. 97-146): Springer.

Pandey, C., \& Khare, R. (2012). Impact of job satisfaction and organizational commitment on employee loyalty. International Journal of Social Science \& Interdisciplinary Research, 1(8), 26-41.

Riasat, F., Aslam, S., \& Nisar, Q. A. (2016). Do intrinsic and extrinsic rewards influence the job satisfaction and job performance? Mediating role of reward system. Journal of Management Info, 11(1), 16-34.

Shujaat, S., \& Alam, R. (2013). IMPACT OF NON-MONETARY REWARDS ON EMPLOYEES'MOTIVATION: A STUDY OF COMMERCIAL BANKS IN KARACHI. IBT Journal of Business Studies (JBS), 9(2).

Solomon, C. M. (1992). Loyalty factor. Personnel journal.

Tausif, M. (2012). Relationship between intrinsic rewards and job satisfaction: a comparative study of public and private organization. International journal of research in commerce, it \& management, 2(6).

Thomas. (2009). Intrinsic motivation at work: What really drives employee engagement: Berrett-Koehler Publishers.

Thomas, K. (2009). The four intrinsic rewards that drive employee engagement. Ivey Business Journal, 73(6), 1-12.

Tippet, J., \& Kluvers, R. (2009). Employee rewards and motivation in non profit organisations: Case study from Australia. International Journal of Business and Management, 4(3), 7-14.

Victor, J., \& Hoole, C. (2017). The influence of organisational rewards on workplace trust and work engagement. SA Journal of Human Resource Management, 15, 14.

Wan, H. L. (2012). Employee loyalty at the workplace: The impact of Japanese style of human resource management. International Journal of Applied HRM, 3(1), 1-17.

Wiklund, F., \& Jansson, S. (2019). Employee Loyalty and the Factors Affecting It: A qualitative study comparing people with different working experience on their view of employee loyalty. 